\title{
Gender as a Dimension of Inequality in Accounting Organizations and Developmental HR Strategies
}

\author{
Faragalla Widad Atena ${ }^{\dagger}$ and Adriana Tiron-Tudor $*+\leftarrow$ (C) \\ Faculty of Economics and Business Administration, Accounting and Audit department, Babes-Bolyai University, \\ 400591 Cluj-Napoca, Romania; faragallaatena@gmail.com \\ * Correspondence: adriana.tiron.tudor@gmail.com \\ t These authors contributed equally to this work.
}

Received: 9 June 2019; Accepted: 24 December 2019; Published: 30 December 2019

\begin{abstract}
Considering the increasing number of women entering the accounting profession, it is timely to explore the inequalities that still exist and consider what policy processes continue to forge inequalities between men and women. Through a systematic literature review (SLR) of accounting and management journals during the period 1994-2017, we assessed the different dynamics that have shaped inequalities between men and women, presenting both the employee and employer perspectives of professional enhancement. The study was framed around conceptualizations of gendered organizations and highlighted how cultural and social practices impact men and women differently. Our study found there are still organization practices that have profound gendered effects. Our study shows that there are contemporary human resource (HR) practices of recruitment, selection, and advancement; perceptions of visibility and invisibility at work; motherhood and childcare responsibilities; and finally, discourses of the glass ceiling that constitute organization and societal barriers that limit women's career progression. Most importantly we reveal that constraints nowadays are similar to those identified in the 90s. We explored these gendered constructions and suggest relevant HR strategies that can aid women's advancement.
\end{abstract}

Keywords: accounting profession; women; gender; inequality; glass ceiling; gendered organizations; diversity management strategies

\section{Introduction}

The accounting profession has been traditionally male-dominated but society has progressed, and nowadays, the context has changed, at least in Europe, where the presence of women in the accounting profession is overwhelming. At the European level, women make up almost two-thirds of the legal and accounting workforce, with Finland, France, and Germany being the countries with the highest number of women in the profession at almost 70\% (Catalyst 2016). More than half of the accountants and auditors are women, making the gender pay gap (Brennan and Nolan 1998) and underrepresentation of women at higher levels a common issue (Lehman 1992; Fogarty et al. 1998; Grey 1998; Catalyst 2016). Even if in some countries, the profession is represented by women as a majority, there is still a vertical segregation; women are still not able to break the ceiling and to achieve equal access to top positions in companies (Ciancanelli 1998).

Understanding organizational practices and processes is central to explaining gender issues. Since the accounting profession is a rigid one, subject to rules that leave no room for flexibility, gender issues are inevitable, and moreover, they are bound to receive a certain level of interest in the literature. The most researched type of accounting firms in the literature are the Big Four's, since the structure of these types of accounting organizations is the most peculiar one (Anderson-Gough et al. 2005; Ciancanelli 1998; Dambrin and Lambert 2008, 2012; $\quad$ Lupu 2012; $\quad$ Kornberger et al. 2010; $\quad$ Mueller et al. 2011; 
Lightbody 2009; Haynes 2008; Kirkham 1992; Whiting and Wright 2001; Brennan and Nolan 1998; Humphrey et al. 2013; Gallhofer and McNicholas 1998). However, the topic of gender issues in accounting organizations remains under-researched (Anderson-Gough et al. 2005; Czarniawska 2008); this paper continues the research in this area done by Tiron-Tudor and Faragalla (2018) by adding the need for solutions to the gendered issues in accounting professional organizations to the discussion.

Therefore, the purpose of this paper was to identify, based on an extensive structured literature review, the primary gender issues and solutions identified in accounting organizations, by researchers in the literature. For this purpose, the following research questions have been formulated:

- How are accounting organizations gendered according to the literature?

- What are the solutions for the gender issues that have been identified by other researchers?

The literature used was not limited to journals from the field of economics, including accounting, finance, business, and other related fields. Journals from the social sciences were considered as well, such as sociology and management, to be sure that the most important gender issues in accounting organizations were captured.

There are other literature reviews that debate some of the gender issues and/or solutions (Hakim 1991; Johnson et al. 2008; Anderson-Gough et al. 2002, 2005; Duff 2011; Czarniawska 2008; Lyonette and Crompton 2008; Lupu 2012; Jeny and Santacreu-Vasut 2017) in accounting organizations (Haynes 2016; Ud Din et al. 2017). However, none of these reviews has tried to synthesize the gendered issues and solutions in accounting organizations in a balanced manner in order to provide a full picture of the gendered nature of accounting organizations. This gap in the literature is addressed by the paper.

The study's originality results from delivering a comprehensive overview of the accounting profession's gendered issues and solutions, placed in an organizational structure to render the women's experiences visible, using the theory of gender stratification, as well as to identify how gender inequality is created and maintained, and what should be the solutions to diminish it. The paper's results and discussions raise awareness for accounting firms showing that a stronger position on gender equality is needed.

The remainder of the paper is organized as follows. In the next part, gender stratification theory creates the theoretical framework of the research, followed by the methodology, and then by the results and discussions (gender issues in the accounting profession and the possible solutions identified for these issues); the last part concludes the paper.

\section{Gender Stratification in Gendered Organizations}

This study embraces the feminist theories that recognize male dominance in social arrangements and articulates a desire to change these patterns of domination (Calas and Smircich 1996). Our interest is in socialist feminist theories regarding the gendering of organizations (Acker 1992a, 1992b). A socialist feminist approach to organizations links the structure of the organization to the people within it by emphasizing that the power-based processes reproducing the gendered structure of the organization also help with producing gendered components of individual identity. This implies that the socialist feminist agenda for changing gender relations in organizations goes well beyond equal opportunities and calls for a transformation of organization's processes and practices (Benschop and Meihuizen 2002).

A generally accepted definition of what gender stratification theory means is that wealth, power, and access to better opportunities are unequal between men and women. In this context, it is relevant to make the difference between gendered and gendering. Acker (1992a, 1992b) stresses that gendered refers to the processes by which certain jobs privilege masculine constructs and gendering, and refers to various discursive strategies to illustrate the fluid and socio-historical dynamic of unveiling gendered norms and practices.

According to Acker (1973), even if the theory is a phenomenon that is not easily quantifiable, it can still be assessed based on certain criteria, such as power, income, privilege, education, association with certain social categories, and so on. When unequal treatment or access is considered in the discussion, 
most of the time it addresses issues such as the pay gap (Brennan and Nolan 1998) and a general misbalance when it comes to the number of women versus the number of men in certain domains (Acker 1973; Blumberg 1984; Chafetz 2006; Keister and Southgate 2012).

The theory nominates a power group by choosing between the two sexes which is the one that is normally most privileged, and that is the male one. The outcome is not unexpected considering that in history, men have always been one step ahead of women since they have always had the right to work. Thus, they had the time to gather the wealth, the higher-ranking positions, and own businesses in key industries. Eventually, the profile of a manager is based on a man's profile and women are expected to rise to the rigors of that profile since most managers are men (Acker 1973).

The aforementioned criteria are included in the power-side category (where there is a hierarchical division between men and women based on social institutions and practices). There are other criteria that cannot be separated from what the theory states; those are class, race, and sexuality, which are embedded at the individual level (Jackson and Scott 2010).

The theory started to gain attention in the 1970s, and up until then, the pay gap, unequal access, unequal distribution of wealth, and lack of opportunity were not considered unnatural; they were seen as a normal and well-deserved inheritance of the so-far-dominated world of men. Up until the point the theory started to gain attention, sex seen as gender was not something that was even considered, it did not exist, and the only stratification that was the object of the debate was the family as a unit (Blumberg 1984; Acker 1973).

The gendered organization theory, much like gender stratification theory, places the issue of men having more power and privilege than women at the center of the debate. The theory states that in every workplace, there are normative expectations that offer an advantage to men as opposed to women. This is reinforced by the gendered assumptions of the universal worker, which is supposed to be disembodied, but which is in fact molded after a man's body. If this is the de facto assumption, it is difficult to regard organizations as gender neutral systems that are influenced by the worker's profile, but rather as contexts and platforms where gendered attributes are created and reproduced. Acker's approach also highlights the ways that gender and other dimensions of inequality become embedded, even in apparently formal, transparent policies and practices, such as workplace evaluation, policies, or job descriptions, that otherwise appear gender neutral. One can argue that an organization is inherently gendered if they have been defined, conceptualized, and are structured in terms of a distinction between masculinity and femininity, and this will inevitably reproduce gender differences (Acker 1973; Metcalfe and Rees 2006; Metcalfe and Woodhams 2012).

Gendered organization theory systematized and made visible all the issues related to gender, such as bias, discrimination, and unequal opportunities, as well as the distribution of privilege (Calás and Smircich 1992; Mills 1992; Mills and Tancred 1992; Tancred and Campbell 1992; Haynes 2016), offering a platform for an open discussion regarding how a balanced gendered organization should look like. The literature and the subjects debated suggest that the retention of women in higher ranks of organizations has stalled; there is a funneling out of women at this level, which in return determines an underrepresentation of women and a profession ruled by men.

Accounting has long been associated with a rational, calculative, middle-class masculinity that prioritizes control, both of the physical world and of the body itself (Burrell 1987). The job is already gendered; therefore, we might expect that this would produce a particular, and relatively stable, kind of masculinity (Britton and Logan 2008).

Acker (1973, 1990, 1992a, 1992b) theory on gendered organizations and institutions, alongside gender stratification theory, might be the key to explaining the gendered impact and how inequalities emerge in the accounting profession.

The gendered organization theory has four dimensions that facilitate the opposition of women working in positions/professions dominated by men.

The first one is the hegemonic masculinity, which implies that organizations construct images and ideologies based on a man's profile, demanding women to follow the rigors of those stereotypes. 
The culturally promulgated image of the ideal manager, for example, means that men always appear to be better candidates for management (Britton and Logan 2008). Manifestations of hegemonic masculinity maintain inequalities in status and power between women and men, and also between men (Connell 1995).

In the case of the accounting profession, one example of the gender hierarchy could be that women are often deemed unworthy of being leaders because they do not fit that profile (Acker 1973, 1990, 1992a, 1992b, 1998, 2004, 2006; Martin and Collinson 2002; Bird and Brush 2002; Britton and Logan 2008; Sayce and Acker 2012; Williams et al. 2012).

The second level is control and segregation, or more precisely, certain mechanisms that would ensure that women are kept in their places and that they cannot breach through the barriers established by a more powerful authority (glass ceiling). The fact that men are more risk-tolerant thus remains intact and undisputed (Bass 1990; Karakowsky and Elangovan 2001). The gendered difference in challenging tasks may result from the task allocation decisions of supervisors who are less willing to assign such tasks to female subordinates than to their male counterparts (De Pater et al. 2010). Second, when women do take on challenging tasks, there is a fair chance that the tasks will be seen as less challenging (Fletcher 1998), so women are often granted less recognition and appreciation for their achievements. These gender differences in challenging tasks may negatively affect women's career progression, which makes gender a highly relevant issue when it comes to showing or having ambition because women do not benefit from the support, recognition, and challenge in the same way as men do. The persistence of gender inequalities hints at the impact of hegemonic masculinities in the social practices of ambition (Benschop et al. 2013; Hakim 2000).

The third and fourth dimensions, regarding gender and gendered personas are linked to stereotypes by associating the personas with certain male or female behaviors, and ultimately holding them gender accountable (Acker 1973, 1990, 1992a, 1992b, 1998, 2004, 2006; Martin and Collinson 2002; Bird and Brush 2002; Britton and Logan 2008; Sayce and Acker 2012; Williams et al. 2012; Haynes 2016). In translation, men are naturally inclined leaders while women are naturally inclined nurturers, making them perfect for jobs such as teachers, doctors, etc. (Dambrin and Lambert 2008).

According to gender stereotypical lines of reasoning, women are not seen as ambitious, and as a consequence, the jobs they are allocated will probably not include challenging tasks (Benschop et al. 2013; Hakim 2000).

Theories and methodologies related to gender, inequality, and a general gap between what a male can achieve versus what a female can with the same skill set and capabilities have been used before in preference theory (Hakim 1991), discussion regarding the glass ceiling (Haynes 2016; Hammond and Oakes 1992; Lehman 1992), and in feminist theories (Ud Din et al. 2017). The authors ground their research on feminist theories in gender accounting research, occupational segregation, and career advancement, bringing the gender differences into the discussion.

For the purpose of our research, gender stratification theory creates the basis of being able to properly identify the gender issues that can be found in gendered accounting organizations and to be able to create a correct picture of what the theory means in the context of these organizations. We highlight the gap in the previous literature reviews, as was stated in the introduction: our approach to addressing this gap is by introducing the gender stratification theory as a lens for our analysis.

\section{Methodology}

\subsection{The Scope of the Literature Review}

The subject of gender in accountancy attracts the interest of the top accounting journals, such as Accounting, Organizations, and Society (1987, vol. 12 (1)); Accounting, Auditing, and Accountability Journal (1992, vol. 5 (3)); Accounting, Organizations and Society (1992, vol. 17 (3/4)); Critical Perspectives on Accounting (1998, vol. 9 (3)); Accounting, Auditing and Accountability Journal 
(2008, vol. 21 (4)); Critical Perspectives on Accounting (2016, vol. 35 (March)); and Accounting History, Accounting History Review, and Meditari Accountancy Research.

This research is focused only on papers that debate modern gender issues of female employees and solutions in accounting organizations, excluding historical perspectives and pioneering women in the accounting profession.

Accounting and large auditing firms organized as partnerships rely on a hierarchy and the standardization of processes to control work and create a stable environment. Nowadays, these firms become more bureaucratic organizations than traditional partnerships (Suddaby et al. 2009). This truth is valid also in the case of medium-sized accounting or audit firms, even if they are professional organizations with policies in place (Mintzberg 1992). Large organizations are complex, with lots of rules and procedures, and with highly trained professionals who have autonomy and considerable power. For these reasons, our focus is on accounting organizations as organizations that are inherently masculine (Britton and Logan 2008).

\subsection{Literature Search Approach}

A structured literature review is a practical methodology used before by Hakim (1991), Johnson et al. (2008), Anderson-Gough et al. (2002, 2005), Duff (2011), Czarniawska (2008), Lyonette and Crompton (2008), Lupu (2012), and Jeny and Santacreu-Vasut (2017). Our choice for this method is given as follows.

A structured literature review is applied when a question needs to be answered by identifying all the relevant articles published on the approached subject and by providing detailed explanations and discussions. Also, it implies an explicit description of what articles will be included and based on what criteria by using a systematic approach. In contrast, a traditional literature review can also start with the desire to answer a question. However, the discussions are kept at a general level; the literature gathered is not necessarily relevant and the reason why some articles are included and why others are not is not explained (Armitage and Keeble-Allen 2008; Dumay et al. 2016; Massaro et al. 2016).

The first step was to establish the questions we wanted to address through the paper. These were:

(a) What are the main gendered issues/impacts in the accounting profession?

(b) What are the possible human resource (HR) strategies/solutions for the gender issues that have been identified?

As a second step, a thorough search was conducted in prestigious, recognized databases (ProQuest Central, Springer Link, Emerald, EBSCO, Scopus) using carefully selected keywords, such as "gender in accounting profession," "women in the accounting profession," "gender in big four," "females," "accountancy," and "gender issues in auditing"; a sample of relevant materials that suited the purposes of the paper was chosen (Massaro et al. 2016). The keywords, which were identified in the titles and abstracts of the papers, were an important aspect when deciding that some articles were to be analyzed, and some were not.

The initial purpose was to identify which were the gendered issues in all possible career paths in the accounting profession (auditing, multinationals, and small accounting practices). After the initial search, we realized that most gendered issues in the literature were found in the Big Four organizations. Thus, we acknowledged that and focused only on these organizations; as such, we narrowed our research to just one type of accounting organization. This was the underlying reason why the keywords "gender issues in auditing" were used.

After establishing the accounting organizations, the third step was to identify the gender issues and the possible solutions to the identified gendered problems. One aspect to be considered was that we took into consideration articles of actuality, and by that, we mean articles that refer to the modern accounting profession and not women in history. 


\subsection{Selection of Articles for Review}

After searching in databases using the established keywords, we received multiple returns, but many of the articles had just one or two of the keywords in the title, and after a brief reading of the abstract, we eliminated them since they did not fit the purpose of the paper. A total of 70 articles remained. Out of this batch, we eliminated the nine that were duplicates and 19 that approached the subject but only briefly, which was not enough to be able to consider them suitable. Table 1 shows the 42 core articles used, presented according to certain criteria. We took into consideration only articles that would be suitable for the purpose of our research and articles that considered gendered issues in the accounting profession and solutions. Also, we looked at the quality of the journals they were published in and at the quality or completeness of their reference list. Therefore, we have eliminated the articles that only briefly mentioned gender issues or solutions and did not focus entirely on the subject.

All the papers that were considered as reference papers in Table 1 were analyzed through the lens of the gender stratification theory in the results and discussions sections.

\subsection{Criteria Used to Analyze the Articles}

The study was based on six criteria: a group of common criteria (year, journal where they were published, and methodology), and a group related to the quality (number of citations and the quartile the published journal was part of). The reason behind choosing these specific criteria was to make sure that the source of the literature review was at a high standard and that the subject of the articles was in accordance with the subject of the paper. To double-check that we covered the most relevant articles for the purpose of the current literature review, the references of the articles selected were analyzed as well and we cross-referenced the results. This cross-reference confirmed that our sample included the most relevant articles for the purpose of our research. 
Table 1. The core articles used for the research.

\begin{tabular}{|c|c|c|c|c|c|c|c|c|}
\hline Authors & Year & Journal & Quartile & Subject & Topic of Article (Approached Gender Issues and Solutions) & Methodology & Method Used & No. of Citations \\
\hline Anderson et al. & 1994 & AOS & Q1 & I & Gender issues impacting on career advancement & Qualitative & Traditional literature review & 140 \\
\hline Anderson-Gough et al. & 2005 & AOS & Q1 & I & Glass ceiling in the Big Four & Qualitative & $\begin{array}{l}\text { Structured literature review and } \\
\text { semi-structured interviews }\end{array}$ & 303 \\
\hline Anderson-Gough et al. & 2002 & ABR & Q1 & I & Career and work structure in a Big Four accounting firm & Qualitative & Case study & 142 \\
\hline Barker and Monks & 1998 & AOS & Q1 & I & $\begin{array}{l}\text { Career progress of men and women and examines the obstacles to progression } \\
\text { encountered by women }\end{array}$ & Qualitative & Literature review and archival data & 108 \\
\hline Benschop et al. & 2013 & $\mathrm{HR}$ & Q1 & $\mathrm{I}, \mathrm{S}$ & Gender and part-time work & Qualitative & Traditional literature review & 38 \\
\hline Benschop and Meihuizen & 2002 & AOS & Q1 & I & Gender representation in the financial field & Qualitative & Traditional literature review & 150 \\
\hline Brennan and Nolan & 1998 & EAR & Q1 & I & Gender pay gap in accounting & Quantitative & Empirical study approach & 18 \\
\hline Carmona and Ezzamel & 2016 & AOS & Q1 & I & Gender in accounting & Qualitative & Traditional literature review & 18 \\
\hline Carnegie and Walker & 2007 & AAAJ & Q1 & I & Gender discrimination in accounting in the early days & Qualitative & Traditional literature review & 44 \\
\hline Charron and Lowe & 2005 & $\mathrm{AF}$ & ESCI & $\mathrm{s}$ & Flexible work schedule approach & Quantitative & Statistical analysis & 29 \\
\hline Ciancanelli & 1998 & $\mathrm{CPA}$ & Q1 & I & Factors that influence gender issues & Qualitative & Traditional literature review & 30 \\
\hline Crompton and Harris & 1988 & BJS & Q1 & I & Occupational segregation and gender differences & Qualitative & Structured literature review & 510 \\
\hline Czarniawska & 2008 & AOS & Q1 & I & Accounting evolution and history & Qualitative & Interviews & 89 \\
\hline Dambrin and Lambert & 2012 & CPA & Q1 & I & The rarity of women at the top levels of the profession & Qualitative & Structured literature review & 66 \\
\hline Dambrin and Lambert & 2008 & AAAJ & Q1 & $\mathrm{I}, \mathrm{S}$ & Motherhood as a primary gender issue & Qualitative & Structured literature review & 125 \\
\hline Duff & 2011 & CPA & Q1 & I & Female representation in the higher ranks in the Big Four & Quantitative & Statistical analysis & 60 \\
\hline Fogarty et al. & 1998 & GMIJ & ESCI & I & Gender issues in public accounting organizations & Qualitative & Case study & 56 \\
\hline Galhofer and McNicholas & 1998 & CAJ & ESCI & I & Gender issues & Qualitative & Traditional literature review & 25 \\
\hline Grey & 1998 & AOS & Q1 & I & Issues of fairness, physical appearance, gender, sexuality, and hierarchy in the Big Four & Qualitative & Structured literature review & 493 \\
\hline Hakim & 1991 & ESR & Q1 & I & Women's motivations (ambitions) in choosing to focus on career or not & Qualitative & Structured literature review & 541 \\
\hline Haynes & 2016 & CPA & Q1 & $\mathrm{s}$ & Gender discrimination in accounting in the last 25 years and future agenda research & Qualitative & Structured literature review & 30 \\
\hline Haynes & 2008 & AOS & Q1 & I & Gendered embodiment of accounting organizations & Qualitative & Traditional literature review & 154 \\
\hline Haynes & 2012 & GWO & Q1 & I & Gendered embodiment of accounting organizations & Qualitative & Semi-structured interviews & 135 \\
\hline Haynes & 2013 & AAA & Q1 & I & Sexuality in the accounting professional environment & Qualitative & Autoethnography & 33 \\
\hline Humphrey et al. & 2013 & IJBAF & Q3 & I & Gender pay gap in accounting & Qualitative & Traditional literature review & 9 \\
\hline Jeacle & 2011 & CPA & Q1 & $\mathrm{s}$ & Women in accounting history and evolution & Qualitative & Traditional literature review & 22 \\
\hline Jeny and Santacreu-Vasut & 2017 & PC & ESCI & I & The rarity of women at the top levels of the profession & Qualitative & Case study & 1 \\
\hline Johnson et al. & 2008 & AOS & Q1 & $\mathrm{s}$ & Flexible work schedule approach & Qualitative & Case study & 80 \\
\hline Kirkham & 1992 & AOS & Q1 & I & History and evolution of women in accounting & Qualitative & Traditional literature review & 185 \\
\hline Kornberger et al. & 2010 & AOS & Q1 & $\mathrm{s}$ & Flexible work schedule approach & Qualitative & Traditional literature review & 165 \\
\hline Lehman & 1992 & AOS & Q1 & I & History and evolution of women in accounting & Qualitative & Traditional literature review & 301 \\
\hline Lightbody & 2009 & $\mathrm{AH}$ & ESCI & $\mathrm{I}, \mathrm{S}$ & Factors that influence gender issues & Qualitative & Case study & 26 \\
\hline Loft & 1992 & AOS & Q1 & I & $\begin{array}{l}\text { How female managers make sense of their career and performance in their organization } \\
\text { (Big Four) }\end{array}$ & Qualitative & Case study & 122 \\
\hline Lupu & 2012 & CPA & Q1 & I & Female representation in the higher ranks in the Big Four, glass ceiling, discrimination & Qualitative & Case study & 52 \\
\hline
\end{tabular}


Table 1. Cont.

\begin{tabular}{|c|c|c|c|c|c|c|c|c|}
\hline Authors & Year & Journal & Quartile & Subject & Topic of Article (Approached Gender Issues and Solutions) & Methodology & Method Used & No. of Citations \\
\hline Lyonette and Crompton & 2008 & GMIJ & ESCI & I & $\begin{array}{l}\text { Female representation in the higher ranks of accounting organizations, } \\
\text { glass ceiling, discrimination }\end{array}$ & Qualitative & Traditional literature review & 53 \\
\hline Mueller et al. & 2011 & CS & Q2 & I & $\begin{array}{l}\text { how female managers, make sense of career and performance in their particular } \\
\text { organization (Big Four) }\end{array}$ & Qualitative & Traditional literature review & 50 \\
\hline Procter and Padfield & 1999 & GWO & Q1 & I & Occupational segregation and gender differences & Qualitative & Traditional literature review & 123 \\
\hline Reed et al. & 1994 & AAAJ & Q1 & I & Factors that influence gender issues & Qualitative & Traditional literature review & 176 \\
\hline Rutteford and Maltbly & 2007 & $\mathrm{AH}$ & ESCI & I & History and evolution of women in accounting & Qualitative & Case study based on interviews & 36 \\
\hline Spruill and Wootton & 1995 & $\mathrm{CPA}$ & Q1 & I & History and evolution of women in accounting & Qualitative & Traditional literature review & 50 \\
\hline Ud Din et al. & 2017 & ER & Q2 & I & $\begin{array}{l}\text { How female managers, make sense of their career and performance in their organization } \\
\text { (Big Four) }\end{array}$ & Qualitative & Traditional literature review & 1 \\
\hline Whiting and Whright & 2001 & BAR & Q2 & I & Gender inequality & Quantitative & Empirical study approach & 76 \\
\hline Windsor and Auyeung & 2006 & $\mathrm{CPA}$ & Q1 & I & Motherhood as a primary gender issue & Qualitative & Empirical study approach & 85 \\
\hline Wright & 2014 & WES & Q1 & I & Work-life balance and gender & Qualitative & Traditional literature review & 19 \\
\hline
\end{tabular}




\section{Results and Discussions}

\subsection{Sample Description}

The articles used were published in the period 1994-2017 in 14 different journals, which were categorized based on the type of the subject they publish according to three main categories. The first one was Accounting, Business, and Economics, which included: Accounting, Auditing \& Accountability Journal (AAAJ), Accounting organizations and society (AOS), Critical perspectives on accounting (CPA), Accounting and Business Research (ABR), Accounting forum (AF), Accounting history (AH), Economic research (ER), British Accounting Review (BAR), Chartered Accountants Journal (CAR), The European Accounting Review (EAR), and International Journal of Business, Accounting and Finance (IJBAF). The second category was Social Sciences: Sociology and Political Science, which included: The British Journal of Sociology (BJS), European Sociological Review (ESR), Oxford University Press (OUP) Journal, Palgrave communications (PC), Current sociology (CS), Human Relations (HR), and Work, employment and society (WES). The last category was Gender Studies-Organizational Behavior and Human Resource Management, which included: Gender work and organization (GWO) journal and Gender in Management: An International Journal (GMIJ). Most articles were published in journals from the area of Accounting, Business, and Economics (28), revealing the interest of researchers toward the accounting domain. The journals that were more inclined to publish gender-related studies in the accounting profession were AOS (eight articles published), CPA (seven articles published), AAAJ (with four articles published), and $\mathrm{AH}$ (two articles published). None of the articles selected were part of a special issue.

Concerning the period, the gendered issues identified were common during the 1990-2017 time span. The challenges faced by women had not changed over the years, with unequal pay, double standards, and the glass ceiling as the most mentioned topics (Brennan and Nolan 1998). Regarding the solutions to these issues that have been debated in the literature, there was a gap of 15 years; they were first debated in an article written in Charron and Lowe (2005). We took into consideration all years as long as the articles were useful for our research. The year of the publications was a means of quantifying when and whether there was an interest for the subject (Wermuth and Monges 2002); thus, regarding the trend of the publications, the peak years were 1992 (3), 1998 (6), 2008 (4), 2011-2012 (6), and 2017 (2), showing an increasing interest over the last few years. Overall, an increase in the number of articles written on the subject was noticed. The first article, written in 1988, was published by Gender in Management: An International Journal (GMIJ) and written by Crompton and Harris; it has the greatest number of citations (510) since it is an article of reference. The article Explaining women's employment patterns: 'orientations to work' revisited discussed gender differences and occupational segregation. The articles written in the peak years 1998 and 2008 were not published in special issues; therefore, this is not the reason for the high number in those years.

Most of the articles in our sample were qualitative studies. Some of the qualitative papers are literature reviews (28), including both traditional (20) and structured (80) literature reviews, while some of them used a case study (9), or interviews (4). The other two are quantitative studies based on the statistical proceedings of data.

To include only relevant articles in the sample as basis for the literature review (Armstrong 1996), the number of citations and the journal's quartile were analyzed as well. The first pillar was comprised five papers with more than 300 citations each (Hakim 1991; Crompton and Harris 1998; Lehman 1992; Grey 1998; Anderson-Gough et al. 2002), and six articles with citations between 100 and 300 each. The second one was composed of 11 articles with between 50-100 citations each, while the other six had less than 50 citations each, but they were recently published papers. The articles that have high citations (over 300) were published in journals such as Accounting organization and society (AOS), Accounting, Auditing \& Accountability Journal (AAAJ), and European Sociological Review (ESR). Regarding the journals' quality, using the quartile criteria, 74\% (31) of the articles used were in the first 
quartile (Q1) according to the journal impact factor, while only 7\% (3) were in Q2, 2\% (1) was in Q3, and the other $17 \%$ (7) were published in journals that are ESCI (emerging sourcing citation index).

The 42 articles selected discussed different subjects in the area of accounting and gender in accounting, such as: the glass ceiling in Big Four companies, female representation in the higher ranks of Big Four companies, motherhood as a primary gender issue, occupational segregation and gender differences, factors that influence gender issues (gender differences in power and income amongst accountants arising not from discrimination but from choice), etc.

Based on the subject discussed, the articles were divided into two categories:

I. Articles that discussed the gendered impacts in the accounting profession.

II. Articles that proposed possible solutions/HR strategies to those issues.

In Table 1, in the subject column, the ones that fell in the first category are marked with an I (impacts), while the ones that fell in the second category are marked with an $\mathrm{S}$ (solutions).

In the foregoing discussion, we show the gendered dynamics of organizations, which have gendered implications, as well as the impact on the opportunities men and women may want to grab hold of at some point.

\subsection{The Accounting Profession and the Key Inequalities Female Employees Face within It}

The most-researched accounting organizations are the big accounting and auditing organizations, such as the Big Four, due to their peculiar work and organizational structure. Most of the studies that have accounting and gender as the primary research objective base their case studies on the large auditing firms. The bureaucratic way they are structured and the flow of work creates the perfect environment for the appearance of gender issues. The routines work as follows: the exclusion of gender as a topic of discussion; silencing and omission of issues concerning gender ambiguity; the crossing of gender boundaries or gender-role inversions; and traditional, stereotypical images of women and men. These routines serve to maintain or even reinforce the hierarchical gender order. Organizations and management hierarchies are gendered; therefore, they will have a gendered impact on the opportunities women and men have (Benschop and Meihuizen 2002).

Most of the studies focus on glass ceiling theory and gender inequality at work for women. There are several studies in the literature that approach the subject of female inequality in the workplace and the effects of the gender stratification theory in Big Four companies (Lupu 2012; Kornberger et al. 2010; Dambrin and Lambert 2008; Duff 2011; Anderson-Gough et al. 2005; Anderson-Gough et al. 2002; Lightbody 2009; Carnegie and Walker 2007).

In Table 2, a brief representation of the most common gendered issues, solutions, and theories is presented:

Table 2. Current research on gender in accounting.

\begin{tabular}{lll}
\hline \multicolumn{1}{c}{ Gender Theories } & \multicolumn{1}{c}{ Gendered Impact } & HR Interventions \\
\hline Gender stratification & Double standard in recruitment and career advancement, & Mentoring \\
Preference & visibility, unequal privilege or opportunity, & Flexible hours \\
Gendered organizations & glass ceiling, lack of representation in higher ranks, & Part-time program \\
Glass ceiling & $\begin{array}{l}\text { discrimination, approved routes, } \\
\text { pay gap, motherhood }\end{array}$ & Overtime \\
& Patime & \\
\hline
\end{tabular}

\subsubsection{Gender Stratification and Gendered Organizations}

Gender as a concept, together with the idea of gendered organizations, not only encompasses the idea that females compared to males are constrained by less favorable contexts inside organizations, but they also try to underly the female versus male characteristics and sometimes try to show which are valued and which are not. Thus, by disregarding some attributes that women have and at the same time valuing the same ones that men also possess, the idea of gender and gendered organizations is 
displayed. Going further with this assumption, by valuing the skills men possess more over the skills women possess inevitably creates power hierarchies, which leads to gender stratification and men becoming the majority that have the power and women the minority who need to adapt and accept when their efforts and input are not valued.

The accounting organizations, such as the Big Four, can be considered as gendered organizations, a fact that is confirmed by the multiple literature reviews highlighting precisely this matter. As early as 1973, Acker started discussing the gendered nature of organizations, stating that most of our working days are spent in organizations dominated by men who are occupying the most powerful positions, bringing the gender stratification issues and the impact on women into the discussion on gender. Since then there are other studies that evaluate gendered organizations, where most of the early inquiries belong to this category (Acker 1973, 1990, 1992a, 1992b, 1998, 2004, 2006; Martin and Collinson 2002; Bird and Brush 2002; Britton and Logan 2008; Sayce and Acker 2012; Williams et al. 2012).

The accounting profession, in its early beginnings, did not have a big female presence (Dambrin and Lambert 2008; Lupu 2012). Female public accountants were hard to find, and up until 1980, the situation had not changed. From 1980 up until 2010, the percentage of women in the profession increased (Lupu 2012; Lightbody 2009; Haynes 2016). In the Big Four companies, the representation of women at higher levels (partners) is not high, between 10-18\%, even though the female representation at lower levels is higher than $50 \%$.

Certain approved routes are already in place that are established to accommodate the profile and skills of men, that are not applicable to women, and as such, are causing mishaps in their careers, creating a favorable context for perpetuating the inequalities. If someone desired to change these approved routes and propose some other paths, or other ways of looking at career development and career advancement, it would cause more harm than good since these routes are not approved, they are gendered and biased, and they would also lack legitimacy, thus they would cause women's careers to derail (Duff 2011; Anderson-Gough et al. 2005; Lupu 2012; Rutteford and Maltby 2007; Haynes 2016). A possible explanation might be the alleged lack of ambition of women (Hakim 1991).

There are studies focusing on glass ceiling theory and gender inequality in accounting organizations. Several of them approach the subject of female inequality at the workplace, or more precisely, the effects of the gender stratification theory and double standards in the Big Four companies (Lupu 2012; Kornberger et al. 2010; Dambrin and Lambert 2008; Duff 2011; Anderson-Gough et al. 2005; Anderson-Gough et al. 2002). Others analyze the rarity of women in higher ranks (Mueller et al. 2011; Jeny and Santacreu-Vasut 2017; Crompton and Harris 1998; Loft 1992).

\subsubsection{Double Standards in Recruiting}

One of the practices that is common in the large auditing companies in certain countries is to recruit only from certain types of environments because this practice would assure the same standards between employees, it would secure the same background, and it is believed that the candidates would be better than others in terms of how fast they learn the process. Another aspect that is taken into consideration when recruiting only from pools of candidates that have a certain kind of background is the fact that they belong to the upper class, and in most cases, they already have a pre-established network of people in high places and with financial power that could become clients over time (Lupu 2012; Kornberger et al. 2010).

Aside from having the necessary intelligence to be able to understand requirements fast, recruiting from the same background would also ensure the same behavior and the same orientation toward the company's values and principles (Lupu 2012).

Even in the cases where women had better academic results than men, this was not taken into consideration. In some situations, when recruiting, HR managers were told to be harder on women, thus to give preferential treatment to men. This way, they would make sure that the number of women was not unnecessarily high, which reduces the impact of maternity leave on the company (Mueller et al. 2011). 
The Big Four organizations are viewed in a certain way; the general impression is that they are intense and that the work is very fast-paced. What some of the studies have observed is that the employees who are part of Big Four do not seem to be bothered by long hours and the atypical manner of working. For them, it seems normal, especially since one of the HR strategies is to recruit people from the same background, which would create a sense of competition and a sense of belonging to a certain group (Anderson-Gough et al. 2005; Lehman 1992).

\subsubsection{Double Standards in Career Advancement}

Career advancement for professional women (Davidson and Cooper 1992) has long been recognized as problematic because gender discrimination impacts on female accountants in terms of a potential promotion (Brennan and Nolan 1998).

The lifestyle and the organizational structure, promotional reasons, and the level of responsibility are hard to understand for individuals who have not worked in a company like these ones. The differentiating factor between women and men is time, which in the case of women, is more stringent. They must fit more activities, including those involving their personal life and the children, in the same amount of time. This is the reason why they will prefer to allocate less time to creating connections and to creating a valuable network, and why in some cases, they will be left behind men when the time to promote to partner positions arrives. Often, they will choose to dedicate whatever free time they have to personal issues rather than using that time for chatting and trying to make connections (Anderson-Gough et al. 2005; Lehman 1992).

Personal responsibilities, such as having a family, will lead to women's careers taking a different turn when they have children. The absence from work will mean that some of them will miss the rising up the career ladder; thus many of them will end up in different, inferior positions in comparison with the same generation peers (Lehman 1992).

One aspect that differentiates men from women is that men are more socially active than women; they tend to socialize more and make more connections. Women, on the contrary, are under the impression that if they work hard, they will be promoted based on the good quality hard work they did. However, as shown in the literature, this is not often the case (Mueller et al. 2011).

Another factor that causes gender issues is that one of the biggest barriers that women encounter when trying to reach positions of power is that they must get through men who are the ones making all the decisions. If the men were objective, there would be no issue, but since they tend to select people that look more like them, meaning those who fit their profile, it is hard to do be objective. They will rarely go for women, and women will most of the time be overlooked (Anderson-Gough et al. 2005).

\subsubsection{Double Standard in the Remuneration Level}

The gender pay gap or gender wage gap refers to the difference in the level of remuneration between men and women for the same position, profile, and skill set. The most common reasons for which the gender pay gap exists are discrimination, motherhood, factors deriving from the industries (some of them are more masculine, thus less inclined to accept women), and the gender roles individuals partake (men are more inclined to be leaders and have initiative while women are softer).

The impact of the gender pay gap reflects at a macro level, in the economy in general, but also at a micro level, affecting women's future prospects and learning curve. The measures taken involve campaigns that are meant to bring awareness, flexible work schedules, and laws that should prevent the perpetuation of the double standard.

\subsubsection{Visibility and Appearance}

The career model in professional accounting organizations implies continuous promotion and progression, meaning that things move at a fast pace promotion-wise. Usually, contexts differentiate when it comes to women if they do decide to have children (Eagley and Carli 2007). If they decide to 
take that step, they will stop working for a short or long while, a time during which business will go on as usual, and they will be at a loss and left behind.

One of the essential aspects that is taken into consideration when working in a big auditing firm is that visibility is one of the factors that helps one become promoted faster, or at least increases one's chances of getting promoted. To have visibility is important to make your presence known, such as always having something to communicate and imposing the views that one might have. It is also a personality trait, i.e., you are either vocal or you are not (Anderson-Gough et al. 2005, 2002; Wright 2014).

This means that some employees are more visible than others. In the category of employees that are not that visible most of the time, women make up the majority. According to a partner in a Big Four company, women were more discreet, less visible, and had the wrong impression that being good on the technical side of things was enough, and that approach was seldom good. On the contrary, men spend time showcasing their achievements, and promotions are based on that aspect. As previously mentioned, this is called gendered socialization, which represents a source cause of inequality between men and women (Czarniawska 2008).

The organizational culture in the Big Four makes visibility one of the crucial aspects that can lift or bring down your career. Therefore, women are often penalized regarding their career advancement due to their lack of visibility. Furthermore, maternity makes it even harder for women to make themselves seen since they are interrupting their careers. Once they return, they are marginalized, and visibility is hard to be achieved when their portfolio of clients is taken from them (Crompton and Harris 1998).

\subsubsection{Glass Ceiling}

Nevertheless, there are invisible barriers, such as the fact that the director positions are occupied by women in a proportion of $60 \%$ because it is the endpoint of their careers in a Big Four. The level is dedicated to those who were senior managers for a long time and who will never make partner (Ciancanelli 1998). These spots are usually reserved for people who do not have the skills to search for clients and negotiate fees. Two more reasons can explain women's rarity at the top levels of organizations. The first one is that when women know that they are going to reach that certain point in their life, they start having other priorities. Thus, they start separating themselves from the group. As a direct consequence, the another reason refers to the idea that women themselves choose a different career path in the hopes of finding a better balance between their personal and professional lives. These career paths are different from what other colleagues are choosing, which is causing disruption and alienation from the path toward partnership and career advancement (Mueller et al. 2011; Loft 1992).

\subsubsection{Motherhood as a Primary Gender Issue}

As discussed by other researchers (Dambrin and Lambert 2008; Windsor and Auyeung 2006; Lupu 2012), the main factor that does not allow women to climb up the hierarchical ladder is motherhood, as cruel as it may sound. Why is this? Because in that line of work, in the accounting context, motherhood is still seen as something that is a drawback that holds back women from being committed to their job and from giving one hundred per cent.

Motherhood has become a recurring reason in the literature, and every time an article approaches the subject of female and career advancement, motherhood is the primary aspect highlighted as a reason for women not being promoted. Motherhood is not directly stated as a fundamental reason; other reasons are brought up, such as lack of focus, not spending so much time as before on the job, and preoccupation with aspects other than work. In the end, all these reasons are in direct relation to the new role women have and are an issue only when women are reaching that point in their lives (Mueller et al. 2011; Loft 1992).

Many times, when pregnancy becomes public, it is not looked upon positively, especially when it happens during the peak season. Women start to get marginalized, and their importance and presence 
reduce gradually in order to diminish the impact of their departure. In many cases their portfolios are taken and redistributed on a timely basis, and upon returning, they are given low-priority clients in order to minimize the impact of them not being able to give one hundred per cent to their jobs (Dambrin and Lambert 2008; Spruill and Wootton 1995; Charron and Lowe 2005).

\subsubsection{Accounting as an Embodied Profession}

The relationship between the body and the self of female accountants refers to the way they start to embody the identity of an accountant and how the organizational and professional structures and environment start to affect self-embodiment and the changes experienced during motherhood.

Acker (1990), followed by Haynes $(2008,2013)$, consider accounting as a professionalized masculinized occupation, which associates the male body imagery as representing competence and capability, while women's bodies are different, out of place, and marginalized.

According to Acker (1990), the accounting profession is a strongly masculinized one, the universal worker is associated with the body and image of a male, along with the associated traits and competencies, such as competence, capability, and sexuality. However, the organizations are not impacted by the individual characteristics that males and females possess, but rather the distinction between the two genders is made inside organizations over time. Thus, organizations are not gender neutral by default and the individuals are the ones defining and labeling a certain organization as gendered, where employees create and nurture the idea of gendered institutions where women's capabilities are ignored and disregarded.

Haynes $(2008,2013)$ and Metcalfe (2008) have analyzed the relationship between the body, which has become more and more a commodity, and the self, and more precisely, the gendered aspects of the self, taking into consideration aspects related to feminist and sociological theories. The embodiment, as clearly explained by Haynes (2016) "refers to the perception that the body of an individual, represents a particular form of identity." The bodies are gendered by nature since they are part of different categories, such as race, class, and age, which in turn create one's identity.

There are certain practices that need to be embodied and adopted, such as the physical aspect, discourse, and behavior in order to transform a woman into an accounting professional. For example, Duff (2011) argues that the images of accounting individuals portrayed in the annual report are evidence for discrimination and stereotyping. The duality of body/self (mind) relates to another one, the one of a male and female. According to the literature, they have been connected due to other overly used stereotypes: the mind (science, knowledge, power of information) is associated with men, while the body (nurturers, emotions) is associated with women.

However, in order to be able to embody those aspects that could help them transform into an accounting professional, it is important that organizations become favorable for such transformations. There are still a lot of structural and cultural barriers that are in the way of women's career advancement, including bias in the process of recruiting and bias in the opportunities offered at work (Metcalfe 2008).

As Haynes perfectly highlights that personal identities are gendered by nature, a fact that cannot be changed. This is bound to intersect with the professional identity since gendered personal identities do not exist in a bubble, but rather they intersect with multiple other factors that ultimately influence the decisions the individual makes. The individuals that are accounting professionals create the gendered accounting organizations and professions. It is ultimately a vicious circle, and the only way to make sure gender identities do not clash when they intersect is to create an organizational environment that is aware and open to the idea of change.

\subsection{Debated HR Strategies and Solutions in the Literature for the Most Common Gender Issues}

Human resource strategies include part-time work possibilities, childcare facilities, flexibility of working hours, pregnancy, maternity and parental leave of absence, career development, training and education, and in- and outflow of personnel (Benschop and Meihuizen 2002). 


\subsubsection{Solutions to Survival in Employment after Motherhood}

One of the main gendered issues that appears often in the literature is motherhood and supposes a period or periods of interruption from work (career breaks). Thus, women facing the challenges of having to balance work life with family life start taking measures to achieve this and behave differently. According to Dambrin and Lambert (2008), they start organizing themselves over time to be prepared for the future. They start delegating their assignments and make sure they choose the right persons to do them to be able to recover their clients once they get back (Reed et al. 1994). The second way women try to manage motherhood and their work life is by starting to impose different work habits on their team, like starting work earlier, taking no breaks, including lunch breaks, and finishing work earlier by a certain time. These work practices that were imposed were not necessarily received without backlash since these women were imposing crazy deadlines on their team members with the same workload as before (Barker and Monks 1998; Lehman 1992).

The alternative solution provided by organizations is offering women positions that do not require them to be the interface for the clients or to interact that much with them. Positions in the taxation department that would allow them to hold positions of management but at the same time to have more time for families are starting to be a more desirable practice. These kinds of practices would ensure that they do not have to travel like they had to do when they were an auditor and that they could still have growth in their careers. Another alternative is having human resources positions that would ensure the same facilities as the taxation ones (Barker and Monks 1998; Kornberger et al. 2010; Lehman 1992).

\subsubsection{The Flexible Hours Approach}

The flexible hours approach (Kornberger et al. 2010; Charron and Lowe 2005; Johnson et al. 2008) is an HR strategy presented in the literature.

The idea of flexible hours emerged as a need for finding solutions for gendered issues to achieve balancing work and family. Flexible work practices are generally recognized now as critical to supporting career opportunities, but flexible work is often still gender-stereotyped as only for women. Flexible and part-time working arrangements should also be available for males to encourage industry-wide participation.

Flexible hour programs mean that every employee that wanted to be a part of the program could decide on their own what that means for them. From this discourse, one could understand that the workload one could take was negotiable. The whole idea of a flexible program is presented as something that is entirely up to the individual (Acker 1990; Jeny and Santacreu-Vasut 2017).

The agenda of creating an environment where women will be comfortable enough to work in a company and stay long enough to become seniors, and later on partners, was set in place in 2001 in a particular firm (Kornberger et al. 2010; Ud Din et al. 2017; Charron and Lowe 2005). The program was intended to be used by all employees, including both men and women, but as expected, women with families were the ones that were the primary beneficiaries. The number of women utilizing this option increased exponentially, but the same thing cannot be said about the number of men (Kornberger et al. 2010).

The reasons that made the firm take the decision to implement flexible hours were, first of all, that the labor market for qualified accountants was not extremely lucrative, and second, that the partners in the firm believed that having gender equality in the company is good for business (Kornberger et al. 2010; Anderson-Gough et al. 2005; Charron and Lowe 2005).

The idea was promoted by the senior equity partner responsible for people and performance. All the senior partners and the CEO were advocates for the program and believed that it would benefit the business, and that it was also the right and ethical thing to do. In short, everybody was on board and thought it was a great initiative, one that would help promote talented women and increase their number in senior positions. In the firm, the program called the gender initiative was comprised of several programs, such as a businesswoman of the year contest, a female mentoring program, 
events dedicated only for women, and of course, the initiative of flexible hours (Kornberger et al. 2010; Charron and Lowe 2005).

Despite the program and the involvement of the firm, which was trying to secure women in higher ranks, the statistics that were obtained from the company showed that the percentage of women in senior management positions (directors) actually decreased in the period the program run: in 2001, there were $25.57 \%$ women in director positions, but in 2005 , four years into the program, only $23 \%$ were women, and in 2008, the last available data showed only $21 \%$ women (Kornberger et al. 2010; Charron and Lowe 2005).

The decrease could be explained by noting that the promotion from senior auditor to manager meant adding more responsibility to the job and that the technical knowledge was not enough for a management position. The newly acquired status meant managing people, so people skills were necessary, which meant establishing a relation with the clients, and more importantly, bringing in more clients. The company viewed the promotion to a manager level as the step toward becoming a partner, which meant adopting a completely different mindset. Managers needed to start managing and not acting as they would under the supervision of someone else (Mueller et al. 2011).

The way people made sense of flexibility in the Big Four firm was that they did not necessarily reduce the workload to accommodate their personal lives to the job better, but rather that the workload would remain the same and that the time during which they could get the job done would be more flexible. If in one particular day of the week, someone had a personal matter to attend to that required them to leave early, they could do just that, but in return, they would probably stay overtime to make up for the lost hours and finish the job (Johnson et al. 2008).

The flexible hours approach program had two main opposing points: firstly, for some of the employees that were in the program, flexible hours meant that in case they needed, they could come in later, and start their schedule at a later time, but not necessarily that they worked fewer hours. Overall the number of hours was the same. The other point of view was from the employees that were not part of the program and who perceived their colleagues that were in the program as not being serious and committed to their career (Kornberger et al. 2010).

\subsubsection{Part-Time Program}

Women who chose a part-time working program due to family reasons are "freezing" their work ambitions temporarily (Benschop et al. 2013).

The literature refers to this kind of strategy as "mother contracts": flexible, part-time contracts in which working hours are adjusted to school hours, for example, and are designed particularly for women who take care of children. Although part-time work has become widespread, it is also a contested practice within organizations. Part-time workers are often seen as non-ideal, even imperfect, workers who are less committed to the organization and not ambitious in their careers (Benschop et al. 2013). This image is gendered too, as the vast majority of working women work part-time. What is more, the ambitions of part-time working men are not questioned, whereas people often have reservations about the ambitions of full-time working women (Benschop et al. 2013).

\subsubsection{Overtime}

Women who are dedicated to their careers and are working side-by-side with men, thus neglecting their family, are considered not to be good mothers. They are considered to be working like they had no children. Here, a double standard arises. Men, even though they are fathers, are not considered to be bad fathers, because fatherhood is not part of their identity as motherhood is for women. Therefore, even though they need to work side-by-side with men to make it to the top, when they do it, they are judged for it and the social pressure to assume their roles as mothers and reduce their involvement in work life is visible. 


\subsubsection{Mentoring as a Way to Break the Ceiling: Pro and Cons}

Having a mentor is important for career development in the accounting profession. The mentor, who understands the organization's written and unwritten rules, can provide very useful advice, tips, and hints for achievement on the hierarchical ladder.

However, mentoring should be a solution only in certain conditions. First, the mentored should be able to specifically articular what they are looking for and what they hope to gain from the relationship. The main benefit of having a mentor is the ability to learn directly from a person who is in a position the mentored aspires to be in or who is very skilled in leadership, consensus building, and treating different issues, and who shares the same values. The most productive mentoring relationships come from a mutual connection; commonly, a potential mentor prefers to invest their limited time in someone they know. The way to find a mentor can be formal or informal, inside or outside the firm.

The literature considers mentoring as a possible solution to facilitate the access of women to the top management positions. However, if the firm develops an internal mentoring program, there are some limits due to the fact that usually, they assign women to mentors that are women, and men to mentors that are men. Those women who are mentors are usually not the ones with the power inside the organization; thus, they do not have a major role to play, nor do they have influence or power. Thus, they cannot open paths for their pupils that are women as well. It is a vicious circle that never ends (Dambrin and Lambert 2008). The idea of mentoring, although not bad at its core, is producing adverse effects. Instead of giving women more space to advance, it is creating a separate network, aside from the main one. These mentors are not able to introduce their protégées to the main circle of power, or to give advice on career advancement as it should be. It leads to a different problem where women lack role models, or more precisely, women role models whose behavior they can mimic. They are only left with male role models, and often if they are replicating their behavior, it is not accepted since it comes from a woman and not from a man (Lupu 2012).

In an effort to facilitate the access of women to higher hierarchical leaders and to diminish the impact of gender stratification in their organizations, the large auditing companies have taken actions to create professional networks for women, a career watch, and inclusiveness in the leadership program. These women's networks provide exposure and leadership opportunities to women situated at all levels and furthermore facilitates the exchange of knowledge and experience. A career watch program is strongly linked to the mentoring system program mentioned earlier as a solution and it mainly offers women the exposure to certain experiences that could help them develop to their full potential. Also, in order to assess the evolution and to provide a proper feedback, a local committee was put into place.

\subsubsection{Recruitment Transparency}

Open recruitment, written job descriptions and policies, and transparent evaluation and promotion practices might increase the representation of women in management across accounting organizations.

\subsubsection{Leaving the Organization}

Some women employees prefer to balance their work life with their personal life by leaving the accounting organization (Hakim 1991; Procter and Padfield 1999; Rutteford and Maltby 2007). This decision might be influenced by lifestyle preferences. The ones that desire to reconcile the work life with family life will not give priority to work life. However, giving priority to work life is precisely what takes an employee to the top levels of an organization. Thus, women who wish to balance their work life with their family life will never make it to the top (Hakim 1991; Procter and Padfield 1999).

\section{Gaps in the Literature}

An identified gap in the literature is the lack of debate regarding an "external" mentoring system; also, in the case of "internal" mentoring, the debate about differences between formal and informal behavior is missing. Nowadays, many local and national accounting organizations offer online and/or 
in-person mentorship programs. These initiatives pair up-and-coming professionals with established accounting and audit specialists through a structured framework. Another possible way to find a mentor should be to participate at the courses of professional specialization, as well as conferences, workshops, and professional meetings. Whether formal or informal, mentorships are one of the best ways to find a path to advancing in the accounting career (Lupu 2012; Britton and Logan 2008).

Another aspect not explored enough by the literature as a solution is the support from organizations, colleagues, and family that facilitates advancement in the career inside accounting organizations. The literature has not explored until now other possible solutions, such as formal training programs for the development of soft skills or networking. The best connections grow organically, by cultivating rapport with individuals within the company, professional group, or accounting industry; in time, there strong relationships should be developed with people who could potentially help in the career advancement or serve as a mentor (Britton and Logan 2008).

The flexibility in the working schedule or part-time work is not common nor is it regarded positively since the collective impression is that if you work part-time, you do not take your career seriously. To some extent, implementing these solutions looks like only a measure to display some kind of action toward closing the gender gap. As Benschop et al. suggested, there is much hidden potential to be tapped in ambitious part-time workers and women (Benschop et al. 2013). From this perspective, HR departments could improve their action plans and implement better policies that would create a more inclusive environment.

Accounting organizations are making steps toward diminishing the gender impacts. The accounting profession, as any other profession, is a gendered one since one cannot separate the individual traits from the professional ones. We are the sum of our qualities and defects, which transpires in what kind of professional identity one has. The embodiment of the professional accountant, contrary to what Haynes (2016) and Metcalfe (2008) affirm, is the embodiment of the personal identity to which we add professional traits. They cannot be separated. The freedom of speech and the new-found freedom of expressing oneself without barriers should strengthen women's status in organizations, even in times of evident bodily and mental transformation, such as motherhood.

\section{Conclusions}

Professional organizations, like accounting and audit firms, are characterized by hierarchy and the standardization of work processes that creates a stable complex bureaucratic gendered environment. For this reason, Acker's theory of gendered organizations supports our research through an approach that revives the focus on gender as an aspect of structures, rather than individuals (Britton and Logan 2008).

Through this paper, the intention was to identify the gendered issues that are present in these types of organizations and the possible solutions that could help diminish the presence of these issues. In doing so, we took into consideration articles from different research backgrounds (social sciences, economics, humanities, management, etc.), and from different years since we did not consider any specific time span.

One of the opening observations after the articles were analyzed was that the issues remained common over the years analyzed, from 1988 to 2017 (thus women faced the same challenges over the years), while the interest was piqued and solutions proposed 17 years into this range with the first article written by Charron and Lowe (2005). Only a total of eight relevant articles proposed solutions, with the most commonly mentioned ones being a flexible hours approach and mentoring as ways of breaking the glass ceiling. The finding is strongly connected to the theory that was applied to the gender stratification research, which gained focus only in the 70s. Up until that point, the differences between men and women were considered to be normal, which explains why there were not any earlier papers on gender issues in accounting organizations. Equality between sexes as a movement was "born" late, thus determining a later interest in organizations as well (Anderson et al. 1994; Benschop and Meihuizen 2002). 
This paper reveals that accounting organization practices create hierarchies in pay grades and discrimination against women, and this is due to the fact that men are preferred for accounting roles. Managerial processes are gendered and they have gendered impacts. Accounting as a gendered profession allows for the formation of inequalities that generate gendered impacts. Among these impacts, the most common in the literature are the pay gap, discrimination, and double standards.

Even if the accounting profession is dominated by women from a number standpoint (at least in European countries, (Lupu 2012; Kornberger et al. 2010)), they still struggle to reach a point where they could honestly state that their status is equal with that of men. Double standards, visibility, and invisible barriers are a major problem nowadays as well. From a gender stratification theory perspective, the issues mentioned above are mainly related to social practices and institutions, thus they are a constraint of the organization's women are part of, organizations that have been inherently male-dominated and have created standards based on a male profile.

In this case, where women have an overwhelming presence, gender-related issues are bound to affect accounting organizations. Aside from the ones mentioned above, another gender issue that affects women's career advancement is motherhood, especially in big accounting and auditing organizations. Motherhood is perceived as a drawback since it is considered to diminish the chances for career advancement and also diminishes the focus on the job. From a gender stratification standpoint, the issues are normally embedded at the individual stratification level since motherhood is a personal choice; however, how organizations react to the idea of motherhood also makes it an institutional dimension of the gender stratification theory. Motherhood is a complex factor that is often present in the literature, and it seems that it is a complex factor from a gender stratification point of view since it is both embedded at the individual and institutional levels. Most of the gender issues are embedded at an institutional level since it is the prerogative of the institution to approach gendered issues appropriately (Benschop et al. 2013; Jeacle 2011; Carmona and Ezzamel 2016).

The presence of double standards constitute another gender issue that is very common in organizations, causing problems in career advancement. Women are perceived through profiles that are molded after males, making it difficult for them to secure jobs in certain domains or certain positions that are inheritably perceived as being masculine, which is in line with Acker (1990) hegemonic masculinity dimension of gendered organization theory. Moreover, in the accounting organizations, procreation, child-rearing, and stereotypically feminine emotions upset the successful functioning of jobs, making it clear again that accounting jobs are based on men's lives, men's bodies, and masculinity, while women are marginalized.

The possible solutions that could diminish the impact of gendered issues found in the literature are analyzed through a discussion of advantages and disadvantages. These solutions refer to introducing flexible hours that are supposed to give women the possibility of better balancing their personal life with work life without neglecting the quality of work they are providing. Another proposed solution is mentoring, which is mostly applied in big accounting and auditing firms. Providing a mentor to a middle-management accountant in order to make sure that the growth is linear is a practice that is meant to reduce gender issues and the effects of gender stratification. Nevertheless, these solutions have their own mishaps; their impact is very easily diminished since most large accounting organizations are strongly gendered and not flexible.

There are quite a few papers that discuss the subject of gender in the accounting profession and the aftermath of these issues. The novelty of the paper is that an analysis of the most relevant papers has been made and has revealed the most common issues women have in accounting organizations and furthermore showing that the issues have been common over the years. The solutions identified were based on the literature and have been presented in order to balance our findings, as well as in the hopes of addressing a gap in the literature. Some unexplored solutions, such as support, networking, and external mentoring, are proposed as well.

One of the limitations of the study is the fact that we had to narrow the research to just one type of accounting organization since there were no studies in the literature (or at least too few) that could 
have offered a base for looking into other types of accounting organizations. Another limitation of the study is the limited number of solutions presented, but this was due to the low number of articles that were considering the subject.

One perspective of the study, which can be considered a limitation as well, is the lack of descriptive statistics that could help better understand the findings of the paper. Another future development for the subject of gendered issues in the accounting profession could be a country level comparison of the most common gendered issues and the actions accounting organizations have taken in order to diminish their impact. Also, analyzing other accounting organizations aside from the Big Four and perhaps comparing the outcomes between their implemented approaches could be another perspective for future research.

In conclusion, we are witnessing the transformation from a male-dominated profession over the past 20 years to a primarily female-dominated one (Franzel 2014). The accounting organizations, in terms of creating gender-balanced representation in upper level management roles, should be aware of changes that may be needed in the organizational structure to help the advancement of women and find solutions to attract new generations with different mentalities, values, and objectives, and maintain female talent inside the company. The global feminist movement, which has determined a series of events with serious consequences, has motivated a worldwide change in perception and in the level of awareness and inclusion. Of course, some regions of the world are more receptive than others, but all things considered, women have more support for career advancement and access to better or at least equal opportunities.

Author Contributions: The authors' individual contribution are the follows: A.T.-T., part 1, 2 and F.W.A., part 3 and 5. Both authors have contributed to part 4 and 6 . All authors have read and agreed to the published version of the manuscript.

Funding: This research received no external funding.

Conflicts of Interest: The authors declare no conflict of interest.

\section{References}

Acker, Joan. 1973. Women and Social Stratification: A Case for Intellectual Sexism. American Journal of Sociology 78: 936-45. [CrossRef]

Acker, Joan. 1990. Hierarchies, jobs, bodies: A theory of gendered organizations. Gender E Society 4: 139-58.

Acker, Joan. 1992a. From sex roles to gendered institutions. Contemporary Sociology 21: 565-69. [CrossRef]

Acker, Joan. 1992b. Gendering organizational theory. Classics of Organizational Theory 6: 450-59.

Acker, Joan. 1998. The future of 'gender and organizations': Connections and boundaries. Gender, Work $\mathcal{E}$ Organization 5: 195-206.

Acker, Joan. 2004. Gender, capitalism and globalization. Critical Sociology 30: 17-41. [CrossRef]

Acker, Joan. 2006. Inequality regimes: Gender, class, and race in organizations. Gender E Society 20: 441-64.

Anderson, John C., Eric N. Johnson, and Philip M. J. Reckers. 1994. Perceived effects of gender, family structure, andphysical appearance on career progression in public accounting: A research note. Accounting, Organizations and Society 19: 483-91. [CrossRef]

Anderson-Gough, Fiona, Christopher Grey, and Keith Robson. 2002. Accounting Professionals and the Accounting Profession: Linking Conduct and Context. Accounting and Business Research 32: 41-56. [CrossRef]

Anderson-Gough, Fiona, Christopher Grey, and Keith Robson. 2005. Helping them to forget: The organizational embedding of gender relations in public audit firms. Accounting, Organizations and Society 30: 469-90. [CrossRef]

Armitage, Andrew, and Diane Keeble-Allen. 2008. Undertaking a Structured Literature Review or Structuring a Literature Review: Tales from the Field. The Electronic Journal of Business Research Methods 6: 103-14.

Armstrong, J. Scott. 1996. The Ombudsman: Management Folklore and Management Science-On Portfolio Planning, Escalation Bias, and Such. Interfaces 26: 25-55. [CrossRef]

Barker, Patricia C., and Kathy Monks. 1998. Irish women accountants and career progression: A research note. Accounting, Organizations and Society 23: 813-23. [CrossRef] 
Bass, Bernard M. 1990. Bass \& Stogdill's Handbook of Leadership: Theory, Research E Managerial Applications. New York: Free Press, London: Collier Macmillan.

Benschop, Yvonne, and Hanne E. Meihuizen. 2002. Keeping up gendered appearances: Representations of gender in financial annual reports. Accounting, Organizations and Society 27: 611-36. [CrossRef]

Benschop, Yvonne, Marieke van den Brink, Hans Doorewaard, and Joke Leenders. 2013. Discourses of ambition gender and part-time work. Human Relations 66: 699-723. [CrossRef]

Bird, Barbara, and Candida Brush. 2002. A gendered perspective on organizational creation. Entrepreneurship Theory and Practice 26: 41-65. [CrossRef]

Blumberg, Rae Lesser. 1984. A general theory of gender stratification. Sociological Theory 2: 23-101. [CrossRef]

Brennan, Niamh, and Patrick Nolan. 1998. Employment and remuneration of Irish chartered accountants: Evidence of gender differences. The European Accounting Review 7: 237-55. [CrossRef]

Britton, Dana M., and Laura Logan. 2008. Gendered organizations: Progress and prospects. Sociology Compass 2: 107-21. [CrossRef]

Burrell, Gibson. 1987. No Accounting for Sexuality. Accounting, Organizations, and Society 12: 89-101. [CrossRef]

Calás, Marta B., and Linda Smircich. 1992. Using the " $F$ " word: Feminist theories and the social consequences of organizational research. In Gendering Organizational Analysis. Edited by A. Mills and P. Tancred. Newbury Park: SAGE Publications, pp. 222-35.

Calas, Marta B., and Linda Smircich. 1996. Thematic Editorial on Gender, Race, Class and Organization. Organization 3: 459-60. [CrossRef]

Carmona, Salvador, and Mahmoud Ezzamel. 2016. Accounting and lived experience in the gendered workplace. Accounting, Organizations and Society 49: 1-8. [CrossRef]

Carnegie, Garry D., and Stephen P. Walker. 2007. Household accounting in Australia: Prescription and practice from the 1820s to the 1960s. Accounting, Auditing \& Accountability Journal 20: 41-73.

Catalyst. 2016. Quick Take: Women in Accounting. Available online: https://www.catalyst.org/knowledge/ women-accounting (accessed on 15 August 2019).

Chafetz, Janet Saltzman, ed. 2006. The Varieties of Gender Theory in Sociology. In Handbook of the Sociology of Gender. New York: Springer, pp. 3-24.

Charron, Kimberly Frank, and D. Jordan Lowe. 2005. Factors that affect accountant's perceptions of alternative work arrangements. Accounting Forum 29: 191-206. [CrossRef]

Ciancanelli, Penny. 1998. Survey research and the limited imagination. Critical Perspectives on Accounting 9: 387-89. [CrossRef]

Connell, Robert. 1995. Masculinities. Cambridge: Polity Press.

Crompton, Rosemary, and Fiona Harris. 1998. Explaining women's employment patterns: 'orientations to work' revisited. The British Journal of Sociology 49: 118-36. [CrossRef]

Czarniawska, Barbara. 2008. Accounting and gender across times and places: An excursion into fiction. Accounting, Organizations and Society 33: 33-47. [CrossRef]

Dambrin, Claire, and Caroline Lambert. 2008. Mothering or auditing? The case of two Big four in France. Accounting. Auditing \& Accountability Journal 21: 474-506.

Dambrin, Claire, and Caroline Lambert. 2012. Who is she and who are we? A reflexive journey in research into the rarity of women in the highest ranks of accountancy. Critical Perspectives on Accounting 23: 1-16. [CrossRef]

Davidson, Marilyn J., and Cary L. Cooper. 1992. Shattering the Glass Ceiling: The Woman Manager. London: Chapman.

De Pater, Irene E., Annelies EM Van Vianen, and Myriam N. Bechtoldt. 2010. Gender differences in job challenge: A matter of task allocation. Gender, Work, and Organization 17: 433-53.

Duff, Angus. 2011. Big four accounting firms annual reviews: A photo analysis of gender and race portrayals. Critical perspectives on Accounting 22: 20-38. [CrossRef]

Dumay, John, Cristiana Bernardi, James Guthrie, and Paola Demartini. 2016. Integrated reporting: A structured literature review. In Accounting Forum. Milton Park: Taylor \& Francis, vol. 40, pp. 166-85.

Eagley, Alice H., and Linda L. S. Carli. 2007. Women and the labyrinth. Harvard Business Review, 63-71. Available online: https://hbr.org/2007/09/women-and-the-labyrinth-of-leadership (accessed on 27 December 2019).

Fletcher, Joyce K. 1998. Relational Practice: A Feminist Reconstruction of Work. Journal of Management Inquiry 7: 163-86. [CrossRef] 
Fogarty, Timothy J., Larry M. Parker, and Thomas Robinson. 1998. Where the rubber meets the road: Performance evaluation and gender in large public accounting organizations. Women in Management Review 13: $299-311$. [CrossRef]

Franzel, Jeanette M. 2014. Leadership in Public Accounting Firms: Why So Few Women? Washington, DC: Public Company Accounting Oversight Board (PCAOB).

Gallhofer, S., and P. McNicholas. 1998. Gender issues-An international comparison. Chartered Accountants Journal 77: 38-40.

Grey, Christopher. 1998. On being a professional in a 'Big Six' firm. Accounting, Organizations and Society 23: 569-87. [CrossRef]

Hakim, Catherine. 1991. Grateful slaves and self-made women: Fact and fantasy in women's work orientations. European Sociological Review 7: 101-21. [CrossRef]

Hakim, Catherine. 2000. Introduction: A social science theory for the 21st century. In Work-Lifestyle Choices In the 21st Century: Preference Theory. Edited by Catherine Hakim. Oxford Oxfordshire: Oxford University Press, p. 7.

Hammond, Theresa, and Leslie S. Oakes. 1992. Some Feminisms and Their Implications for Accounting Practice. Accounting, Auditing \& Accountability Journal. 5. Available online: https:/www.emerald.com/insight/content/ doi/10.1108/09513579210017389/full/html (accessed on 27 December 2019).

Haynes, Kathryn. 2008. (Re)figuring accounting and maternal bodies: The gendered embodiment of accounting professionals. Accounting, Organizations and Society 33: 328-48. [CrossRef]

Haynes, Kathryn. 2013. Sexuality and sexual symbolism as processes of gendered identity formation: An autoethnography of an accounting firm. Accounting Auditing \& Accountability Journal 26: 374-98.

Haynes, Kathryn. 2016. Accounting as gendering and gendered: A review of 25 years of critical accounting research on gender. Critical Perspectives on Accounting 43: 110-24. [CrossRef]

Humphrey, R. L., M. V. Moore Johnson, and B. Pullum. 2013. An investigation of wages as gender shifts in the accounting profession. International Journal of Business, Accounting, E Finance 7: 9-20.

Jackson, Stevi, and Sue Scott. 2010. Rehabilitating Interactionism for a Feminist Sociology of Sexuality. Sociology 44: 811-26. [CrossRef]

Jeacle, Ingrid. 2011. A practice of her own: Female career success beyond the accounting firm. Critical Perspectives on Accounting 22: 288-303. [CrossRef]

Jeny, Anne, and Estefania Santacreu-Vasut. 2017. New avenues of research to explain the rarity of females at the top of the accountancy profession. Palgrave Communications 3: 17011. [CrossRef]

Johnson, Eric N., D. Jordan Lowe, and Philip M. J. Reckers. 2008. Alternative work arrangements and perceived career success: Current evidence from the big four firms in the US. Accounting, Organizations and Society 33: 48-72. [CrossRef]

Karakowsky, Leonard, and A. R. Elangovan. 2001. Risky Decision Making in Mixed-Gender Teams: Whose Risk Tolerance Matters? Small Group Research 32: 94-111. [CrossRef]

Keister, Lisa A., and Darby E. Southgate. 2012. Inequality: A Contemporary Approach to Race, Class, and Gender. Cambridge: Cambridge University Press.

Kirkham, Linda M. 1992. Integrating herstory and history in accountancy. Accounting, Organizations and Society 17: 287-97. [CrossRef]

Kornberger, Martin, Chris Carter, and Anne Ross-Smith. 2010. Changing gender domination in a Big Four accounting firm: Flexibility, performance and client service in practice. Accounting, Organizations and Society 35: 775-91. [CrossRef]

Lehman, Cheryl R. 1992. Herstory in accounting: The first eight years. Accounting organization and Society 17: 262-85. [CrossRef]

Lightbody, G. Margaret. 2009. Turnover decisions of women accountants: Using personal histories to understand the relative influence of domestic obligations. Accounting History 14: 55-78. [CrossRef]

Loft, Anne. 1992. Accountancy and the gendered division of labour: A review essay. Accounting, Organizations and Society 17: 367-78. [CrossRef] 
Lupu, Ioana. 2012. Approved routes and alternative paths: The construction of women's careers in large accounting firms. Evidence from the French Big Four. Critical Perspectives on Accounting 23: 351-69. [CrossRef]

Lyonette, Clare, and Rosemary Crompton. 2008. The only way is up? An examination of women's "under-achievement" in the accountancy profession in the UK. Gender in Management: An International Journal 23: 506-21. [CrossRef]

Martin, Patricia Yancey, and David Collinson. 2002. Over the pond and across the water': Developing the field of 'gendered organizations. Gender, Work E Organization 9: 244-65.

Massaro, Maurizio, John Dumay, and James Guthrie. 2016. On the shoulders of giants: Undertaking a structured literature review in accounting. Accounting, Auditing \& Accountability Journal 29: 767-801.

Metcalfe, Beverly Dawn. 2008. A feminist poststructuralist analysis of HRD: Why bodies, power and reflexivity matter. Human Resource Development International 11: 447-63. [CrossRef]

Metcalfe, Beverly Dawn, and C. Rees. 2006. Feminism, Gender and HRD. In Critical Human Resource Development: Beyond Orthodoxy. Edited by Kiran Trehan, Clare Rigg and J. Stewart. Upper New Jersey River: Prentice Hall.

Metcalfe, Beverly Dawn, and Carol Woodhams. 2012. Introduction: New Directions in Gender, Diversity and Organization Theorizing-Re-imagining Feminist Post-colonialism, Transnationalism and Geographies of Power. International Journal of Management Reviews 14: 123-40. [CrossRef]

Mills, Albert. 1992. Organization, Gender, and Culture, Gendering Organizational Analysis. Newbury Park: SAGE, pp. 93-112.

Mills, Albert, and Peta Tancred. 1992. Gendering Organizational Analysis. Newbury Park: SAGE, pp. 31-45.

Mintzberg, Henry. 1992. Structure in Fives: Designing Effective Organizations. Upper Saddle River: Prentice Hall.

Mueller, Frank, Chris Carter, and Anne Ross-Smith. 2011. Making sense of career in a Big four accounting firm. Current Sociology 59: 551-67. [CrossRef]

Procter, Ian, and Maureen Padfield. 1999. Work orientations and women's work: A critique of Hakim's theory of the heterogenity of women. Gender, Work and Organization 6: 152-62. [CrossRef]

Reed, Sarah A., Stanley H. Kratchman, and Robert H. Strawser. 1994. Job satisfaction, organizational commitment, and turnover intentions of United States accountants. The impact of the locus of control and gender. Accounting, Auditing and Accountability Journal 7: 31-58. [CrossRef]

Rutteford, Janette, and Josephine Maltby. 2007. "The nesting instinct": Women and investment risk in a historical context. Accounting History 12: 305-27. [CrossRef]

Sayce, S., and Joan Acker. 2012. Gendered organizations and intersectionality: Problems and possibilities. Equality, Diversity and Inclusion: An International Journal 31: 214-24.

Spruill, Wanda G., and Charles W. Wootton. 1995. The struggle of Women in accounting: The case of Jennie Palen, Pioneer Accountant, Historian and Poet. Critical Perspectives on Accounting 6: 371-89. [CrossRef]

Suddaby, Roy, Yves Gendron, and Helen Lam. 2009. The organizational context of professionalism in accounting. Accounting, Organizations and Society 34: 409-27. [CrossRef]

Tancred, Peta, and Jane Campbell. 1992. Room for women: A case study in the sociology of organizations. In Gendering Organizational, Analysis. Newbury Park: SAGE, pp. 31-45.

Tiron-Tudor, Adriana, and Widad Faragalla. 2018. Women Career Paths in Accounting Organizations: Big4 Scenario. Administrative Sciences 8: 62. [CrossRef]

Ud Din, Nizam, Xinsheng Cheng, and Shama Nazneen. 2017. Women's skills and career advancement: A review of gender (in)equality in an accounting workplace. Economic Research 31: 1512-25. [CrossRef]

Wermuth, Laurie, and Miriam Ma'at-Ka-Re Monges. 2002. Gender stratification: A structural model for examining case examples of women in less-developed countries. Frontiers: A Journal of Women Studies 23: 1-22. [CrossRef]

Whiting, Rosalind H., and Christine Wright. 2001. Explaining gender inequity in the New Zealand accounting profession. British Accounting Review 33: 191-222. [CrossRef]

Williams, Christine L., Chandra Muller, and Kristine Kilanski. 2012. Gendered organizations in the new economy. Gender E Society 26: 549-73. 
Windsor, Carolyn, and Pak Auyeung. 2006. The effect of gender and dependent children on professional accountant's career progression. Critical Perspectives on Accounting 17: 828-44. [CrossRef]

Wright, Tessa. 2014. Gender, sexuality and male-dominated work: The intersection of long-hours working and domestic life. Work, Employment \& Society 28: 985-1002. [CrossRef]

(c) (

(C) 2019 by the authors. Licensee MDPI, Basel, Switzerland. This article is an open access article distributed under the terms and conditions of the Creative Commons Attribution (CC BY) license (http://creativecommons.org/licenses/by/4.0/). 